\title{
Thiohalomonas denitrificans gen. nov., sp. nov. and Thiohalomonas nitratireducens sp. nov., novel obligately chemolithoautotrophic, moderately halophilic, thiodenitrifying Gammaproteobacteria from hypersaline habitats
}

Correspondence
Dimitry Yu. Sorokin
soroc@inmi.host.ru
or
D.Y.Sorokin@tnw.tudelft.nl

Hypersaline habitats, such as inland salt lakes and solar salterns, are traditionally regarded as low-diversity environments, dominated by heterotrophic haloarchaea that grow optimally in saturated $\mathrm{NaCl}$ brines (Oren, 2002). Some of the moderately halophilic/extremely salt-tolerant Gammaproteobacteria, such as Halomonas and Marinobacter, better

Abbreviation: SOB, sulfur-oxidizing bacteria.

The GenBank/EMBL/DDBJ accession numbers for the 16S rRNA gene sequences obtained in this study are DQ469580-DQ469581, DQ836238, EF117909-EF117913 and EF455919, and for the nirS gene from strain HLD 2 ${ }^{\top}$, AM492191.

Cytochrome difference spectra of cell-free extract obtained from strain HLD $2^{\top}$ cells grown anaerobically with nitrate and thiosulfate, and graphs showing the influence of $\mathrm{NaCl}$ on anaerobic growth of HLD strains with nitrate and thiosulfate, and on the activity of thiosulfate oxidation by washed cells of strain HLD $2^{\top}$ grown anaerobically are available with the online version of this paper. adapted to lower salinity, have an advantage over less flexible haloarchaea at fluctuating salinity (Ventosa et al., 1998). Recent studies have demonstrated that moderately and extremely halophilic bacteria represent an important component of prokaryotic communities, even under extremely high-salt conditions (Antón et al., 2002; Sorokin et al., 2006a). Furthermore, even chemolithoautotrophic bacteria can be abundant and active under such conditions. In particular, chemolithoautotrophic sulfur-oxidizing bacteria (SOB) have the best chance to adapt to extremely high-salt conditions because of a very high energy yield available during complete oxidation of sulfide/thiosulfate to sulfate (Oren, 1999).

Previously, we demonstrated the potential of haloalkaliphilic SOB belonging to the genus Thioalkalivibrio for growth in saturated soda brines (Sorokin \& Kuenen, 2005). In addition, a large diversity of moderately and even 
extremely halophilic SOB has been discovered in hypersaline habitats with neutral pH (Sorokin et al., 2006b). Among the six different types of halophilic SOB discovered, two groups of aerobic moderate halophiles belong to the known genera Thiomicrospira (Sorokin et al., 2006c) and Halothiobacillus. The latter contains the only SOB species, Halothiobacillus halophilus, which was known previously as being capable of growing at $\mathrm{NaCl}$ concentrations up to $4 \mathrm{M}$ (Wood \& Kelly, 1991). The other four novel groups belong to previously unknown lineages within the Gammaproteobacteria. They include two groups of moderately halophilic thiodenitrifiers and two groups of extreme halophiles.

Here we describe the properties of a novel group of moderately halophilic, obligately chemolithoautotrophic and facultatively anaerobic, sulfur-oxidizing Gammaproteobacteria, consisting of 11 isolates from sediments of hypersaline lakes and a solar saltern. These bacteria dominated the anaerobic enrichment cultures with thiosulfate as electron donor and nitrate as electron acceptor at $2 \mathrm{M} \mathrm{NaCl}$.

Sediments from hypersaline lakes in north-east Mongolia, the Kulunda Steppe (south-west Siberia, Altai, Russia) and the Crimea (Ukraine), Lake Baskunchak (South Russia) and the Sečovlje Adriatic Sea solar saltern were used as inoculum in this work (Sorokin et al., 2006b). In general, the salt content of the brines varied from 10 to $38 \%(\mathrm{w} / \mathrm{v})$ and the $\mathrm{pH}$ ranged from 6.5 to 8.2 ; the dominant ions were $\mathrm{Na}^{+}$, $\mathrm{Mg}^{2+}, \mathrm{Cl}^{-}$and $\mathrm{SO}_{4}^{2-}$.

The following mineral base medium was used for enrichment and growth experiments: $\mathrm{NaCl}, 0.5-3.0 \mathrm{M} ; \mathrm{K}_{2} \mathrm{HPO}_{4}$, $10 \mathrm{mM} ; \mathrm{NH}_{4} \mathrm{Cl}, 5 \mathrm{mM}$. The $\mathrm{pH}$ was adjusted to $7.2-7.5$ with $10 \% \mathrm{KH}_{2} \mathrm{PO}_{4}$. After sterilization, the medium was supplemented with $2 \mathrm{mM} \mathrm{MgCl} 2 \cdot 6 \mathrm{H}_{2} \mathrm{O}$ and $1 \mathrm{ml}$ trace metal solution $\mathrm{l}^{-1}$ (Pfennig \& Lippert, 1966). Thiosulfate (5$20 \mathrm{mM}$ ) or thiocyanate $(5-10 \mathrm{mM})$ were added as electron donors (the range is for aerobic and anaerobic conditions, respectively), and $\mathrm{KNO}_{3}(20 \mathrm{mM}), \mathrm{KNO}_{2}(5 \mathrm{mM}), \mathrm{N}_{2} \mathrm{O}$ ( $10 \%$ in the gas phase) or $\mathrm{O}_{2}(2-20 \%$ in the gas phase) were used as electron acceptors. Filter-sterilized $\mathrm{NaHCO}_{3}(10$ $40 \mathrm{mM}, \mathrm{pH} 8.0$; the range depending on the amount of thiosulfate added) was used as the carbon source and as the $\mathrm{pH}$ buffer. Anaerobic cultivation was routinely performed in $100 \mathrm{ml}$ serum bottles with $80 \mathrm{ml}$ medium, which was made anoxic by five sequential cycles of evacuation-flushing with argon. In the case of aerobic incubations, the liquid/gas ratio was $10: 90$. Cultivation was performed at $30^{\circ} \mathrm{C}$. Growth was monitored by following the optical density at $600 \mathrm{~nm}$ and by qualitative tests for nitrate/nitrite (Merck). Positive enrichment cultures were stabilized by several $1: 100$ transfers and, finally, pure cultures were obtained after several dilution to extinction series. The purity of the cultures was checked by the absence of growth on medium where thiosulfate was replaced by yeast extract $\left(1 \mathrm{~g} \mathrm{l}^{-1}\right)$ and further confirmed by sequencing. Dialysis cultivation and use of sucrose gradient centrifugation to separate a nitrate-reducing strain from the mixed denitrifying enrichment were performed as described previously (Sorokin et al., 2006b).
Nitrogen (nitrate, nitrite, $\mathrm{N}_{2} \mathrm{O}$ ) and sulfur (sulfide, sulfur, thiosulfate, sulfate, thiocyanate, tetrathionate) compounds in growth experiments were analysed as described previously (Sorokin et al., 2001a, b, 2004). Protein concentrations were measured by the Lowry method after removal of interfering sulfur compounds either by washing (thiosulfate, thiocyanate) or by overnight extraction with acetone (sulfur). Cellular fatty acids were extracted with a mixture of methanol/chloroform and analysed by GC-MS according to Zhilina et al. (1997). Phase-contrast micrographs were obtained using an Axioplan Imaging 2 microscope (Zeiss). For electron microscopy, the cells were subjected to cryofixation in glutaraldehyde (final concn $3 \%, \mathrm{v} / \mathrm{v}$ ) at $\mathrm{pH} 7.0$ in the presence of $0.5 \mathrm{M} \mathrm{NaCl}$, then post-fixed in $1 \%(\mathrm{w} / \mathrm{v})$ $\mathrm{OsO}_{4} / 0.5 \mathrm{M} \mathrm{NaCl}$ for $3 \mathrm{~h}$ at room temperature, washed and stained overnight with $1 \%(\mathrm{w} / \mathrm{v})$ uranyl acetate, dehydrated in an ethanol series and embedded in Epon resin. Thin sections were contrasted with $1 \%(\mathrm{w} / \mathrm{v})$ lead citrate.

The isolation of genomic DNA and subsequent determination of the $\mathrm{G}+\mathrm{C}$ content of the DNA were carried out according to Marmur (1961). DNA-DNA hybridization was performed by the thermal denaturation/reassociation technique (De Ley et al., 1970). Genomic DNA for PCR amplification was extracted from the cells using the UltraClean Soil DNA Extraction Kit (MolBio Laboratories) following the manufacturer's instructions. The nearly complete $16 \mathrm{~S}$ rRNA gene was obtained from pure cultures using bacterial primers GM3F and GM4R (Schäfer \& Muyzer, 2001). PCR products were purified from low-melting-point agarose using the Wizard PCR-Prep kit (Promega) according to the manufacturer's instructions. Sequencing was performed using the BigDye Terminator v.3.1 Cycle Sequencing Kit with an ABI 3730 DNA automatic sequencer (Applied Biosystems). The sequences were aligned with those from GenBank using CLUSTAL W. Phylogenetic trees were reconstructed with four different algorithms using the TREECONW software package (Van de Peer \& De Wachter, 1994). Pairwise evolutionary distances (expressed as estimated changes per $100 \mathrm{nt}$ ) were computed by using the method of Jukes \& Cantor (1969). The resulting phylogenetic tree was constructed by the neighbour-joining method. Bootstrap analysis (100 replications) was used to validate the reproducibility of the branching patterns of the trees.

Cytochrome $c d_{1}$-containing nitrite reductase genes (nirS) were amplified from 50 ng genomic DNA from strain HLD $2^{\mathrm{T}}$ using primer pair nirS1F and nirS6R and protocols described previously by Braker et al. (1998). PCR products of the expected size (approx. $890 \mathrm{bp}$ ) were purified with the QIAquick PCR purification kit (Qiagen). Both strands were sequenced directly from the PCR product on an ABI 3100 automated DNA sequencer (Applied Biosystems) using gene-specific primers nirS1F and nirS6R and the BigDye Terminator v3.1 Cycle Sequencing Kit (Applied Biosystems). Forward and reverse strand sequences were assembled by using Seqman II software (DNASTAR) and aligned to 
sequences from the EMBL database with the ARB fast aligner feature (www.arb-home.de). For phylogenetic analysis a filter was calculated to omit insertions or deletions (indels) due to ambiguous positional homology and included 241 aa positions. Analyses were performed with the PHYLIP software package version 3.66 (Felsenstein, 1989). Trees were reconstructed by using the distance-matrix-based neighbourjoining method with the Jones-Taylor-Thornton amino acid replacement model, the parsimony method PROTPARS and the maximum-likelihood method PROTML. Statistical evaluation of tree topologies was performed with 1000 resamplings for each method.

Only nitrate supported thiosulfate oxidation in anaerobic enrichments at $2 \mathrm{M} \mathrm{NaCl}$ with thiosulfate as electron donor and $\mathrm{NO}_{x}$ as electron acceptors. Positive enrichments were obtained from various lake sediments and from the solar saltern. In all cases nitrite and $\mathrm{N}_{2} \mathrm{O}$ were observed as major intermediates of nitrate reduction with $\mathrm{N}_{2}$ as the final product. Thiosulfate was oxidized to sulfate with occasional formation of elemental sulfur (at high levels of nitrite production) as an intermediate. Despite vigorous growth in liquid culture, colony formation could not be achieved, neither on the agar plates in anaerobic jars nor in agar shake tubes. The isolation of pure cultures was only possible after several rounds of serial dilution to extinction with a reduced concentration of nitrate (i.e. 5 instead of $20 \mathrm{mM}$ ) to avoid inhibition by nitrite. Finally, 10 strains (abbreviated as HLD) were isolated in pure culture (Table 1).

All HLD isolates had long, non-motile, rod-shaped cells (Fig. 1a, c). Under unfavourable growth conditions, such as the substitution of $\mathrm{Cl}^{-}$by $\mathrm{SO}_{4}^{2-}$ or $\mathrm{Na}^{+}$by $\mathrm{K}^{+}$(above $50 \%$ ), the formation of cyst-like round cells (Fig. 1b) covered with an extracellular matrix layer (Fig. 1e) was observed. Thin sectioning of one of the strains revealed two interesting ultrastructural features inside the cells. The cytoplasm in the cell tips had a distinct grainy texture, which was clearly different from the more homogeneous middle zone containing the genomic DNA (Fig. 1d). It might be that the growing tips of the cells contain a high number of ribosomes in contrast to the 'old' middle part. Furthermore, in many cells a single- or double-ring structure could be seen (Fig. 1f), which might be mesosomes - a cell membrane extension binding to the chromosome (Silva et al., 1976).
Despite different geographical origins, the HLD isolates consisted of a single gene species according to their $\mathrm{G}+\mathrm{C}$ content (58-60 mol\%) and the results of DNA-DNA hybridization ( $>65 \%$ homology) (Wayne et al., 1987). Phylogenetic analysis of seven isolates from different geographical locations revealed that they formed a separate lineage within the Gammaproteobacteria with 'Thiobacillus prosperus' as the closest culturable relative ( $92 \%$ sequence homology) (Fig. 2a). Analysis of the fatty acid composition of the polar lipids in strain HLD $2^{\mathrm{T}}$ demonstrated a pattern typical for the moderately halophilic Gammaproteobacteria (such as Halomonas), with $\mathrm{C}_{16: 0}, \mathrm{C}_{16: 1}$ and $\mathrm{C}_{18: 1}$ dominant (Table 2).

Cytochrome spectra obtained from cells of HLD $2^{\mathrm{T}}$ grown anaerobically with nitrate showed a profile indicative of the presence of cytochrome $c d_{1}$-type nitrite reductase (supplementary Fig. S1, available with the online version of this paper). This was further supported by detection of the nirS gene (encoding the $c d_{1}$ nitrite reductase) in strain HLD $2^{\mathrm{T}}$ by PCR. The obtained sequence fell into the radiation of gammaproteobacterial nirS genes with highest similarity to the enzyme from heterotrophic, halophilic denitrifiers of the genus Marinobacter (Fig. 2b).

The HLD strains grew best anaerobically with thiosulfate and nitrate. Growth was not observed with either $\mathrm{H}_{2}$ or organic compounds (i.e. acetate, pyruvate and yeast extract) used as electron donors instead of thiosulfate. Sulfate was the final product of thiosulfate oxidation. However, accumulation of nitrite at a high initial nitrate concentration (i.e. $10-20 \mathrm{mM}$ ) was a common problem for all the strains. Nitrite started to inhibit growth at concentrations above 4-5 mM and caused incomplete oxidation of thiosulfate to sulfur and growth inhibition. This can be avoided by providing the nitrate in small portions at low concentrations (3-5 $\mathrm{mM}$ ) after complete reduction of the produced nitrite to $\mathrm{N}_{2}$. In this way the HLD cultures had a relatively high growth yield [4-5 $\mathrm{mg}$ protein $\left(\mathrm{mmol} \mathrm{S}_{2} \mathrm{O}_{3}^{2-}\right)^{-1}$ ] and a maximum growth rate of $0.03-0.04 \mathrm{~h}^{-1}$ at $2 \mathrm{M} \mathrm{NaCl}$. Despite the fact that nitrite and $\mathrm{N}_{2} \mathrm{O}$ were produced as intermediates during anaerobic growth with nitrate, and that washed cells, grown with nitrate, could reduce both intermediates in the presence of thiosulfate, anaerobic growth could be initiated only with nitrate. Growth with

Table 1. Pure cultures of moderately halophilic denitrifying SOB from hypersaline habitats

\begin{tabular}{|lllc|}
\hline Region & \multicolumn{1}{c}{ Type } & \multicolumn{1}{c|}{ Strains } & DNA G+C (mol\%) \\
\hline Kulunda Steppe (south-west & Hypersaline lakes & HLD 1-HLD 5, & $58.0-60.0$ \\
Siberia, Russia) & & HLD 12 \\
North-east Mongolia & Hypersaline lakes & HLD 13 & \\
Lake Baskunchak (South Russia) & Hypersaline lakes & HLD 14 & 59.0 \\
Crimea (Ukraine) & Hypersaline lakes & HLD 15 & 58.8 \\
Slovenia & Sea saltern & HLD 16 & 60.1 \\
& & & 59.5 \\
\hline
\end{tabular}




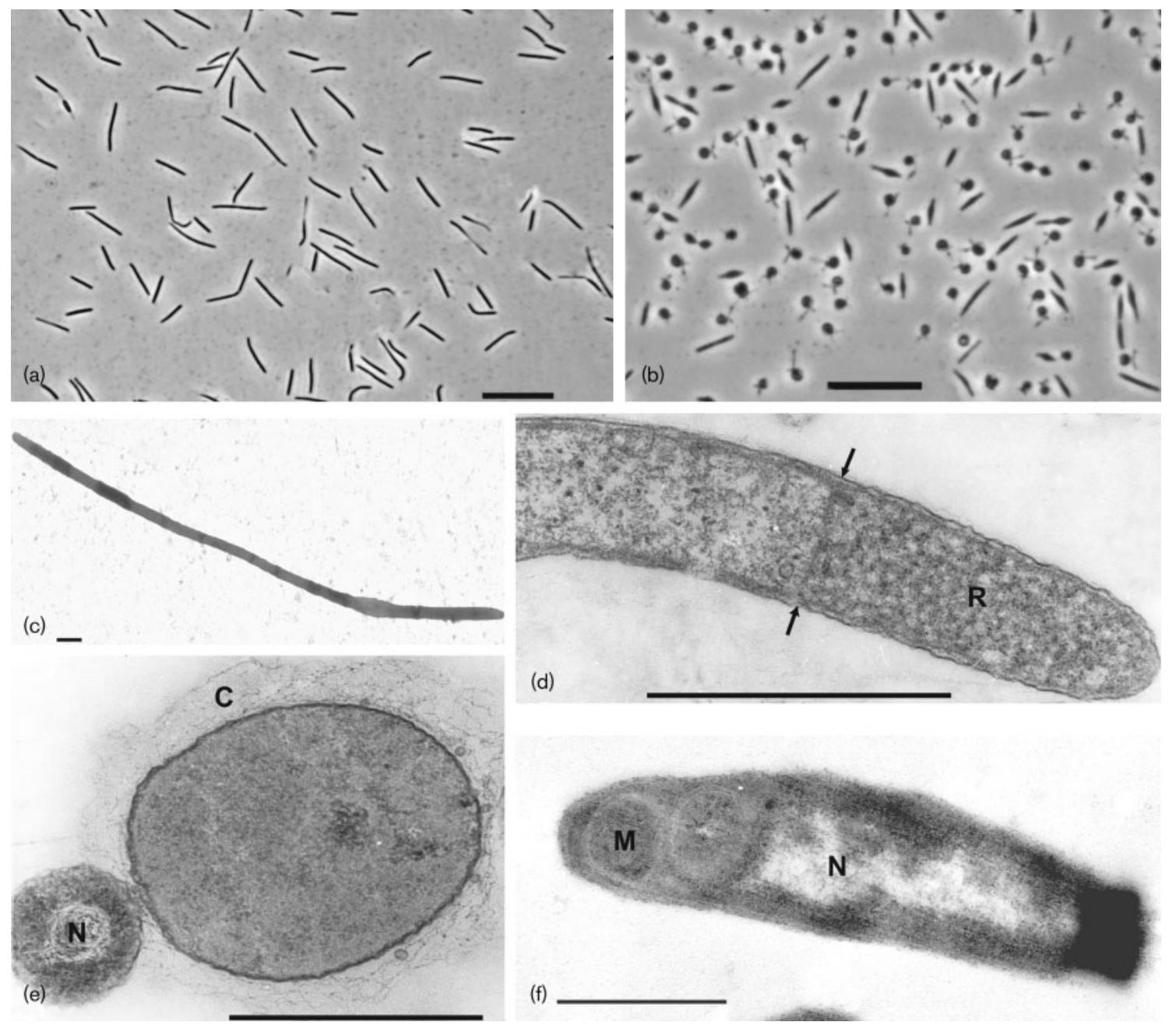

Fig. 1. Cell morphology of moderately halophilic, thiodenitrifying strain $\mathrm{HLD} 2^{\top}$ grown anaerobically with $2 \mathrm{M} \mathrm{NaCl}$. (a, b) Phase-contrast micrographs (bars, $10 \mu \mathrm{m})$; (c-f), electron micrographs of total preparation (c) and thin sections (d-f) (bars, $1 \mu \mathrm{m})$. ( $\mathrm{a}, \mathrm{c}, \mathrm{d}, \mathrm{f})$ Cells grown under normal conditions (2 $\mathrm{M} \mathrm{NaCl}) ;(b, e)$, cyst formation under unfavourable conditions (i.e. replacement of $75 \% \mathrm{Cl}^{-}$by $\mathrm{SO}_{4}^{2-}$ ). N, Nucleoid; R, ribosome-like structures; $\mathrm{C}$, capsule; $\mathrm{M}$, mesosome-like structures; arrows indicate separation of the cells into two different parts.

oxygen instead of nitrate as electron acceptor was less regular. In the case of a few successful incubations, growth was observed under micro-oxic conditions at $\mathrm{O}_{2}$ concentrations between 2 and $5 \%(\mathrm{v} / \mathrm{v})$ in the gas phase. The HLD strains grew within a relatively narrow salt range from 1.0 to $3.0 \mathrm{M} \mathrm{NaCl}$, with an optimal concentration of 1.5-2 M (supplementary Fig. S2a, available with the online version of this paper). Some of them still oxidized thiosulfate at lower salinity with the production of nitrite and elemental sulfur, but without substantial biomass growth. Washed cells, grown anaerobically with nitrate at $2 \mathrm{M} \mathrm{NaCl}$, oxidized thiosulfate most actively with $\mathrm{N}_{2} \mathrm{O}$ as electron acceptor. With all four different electron acceptors $\left(\mathrm{O}_{2}, \mathrm{NO}_{3}^{-}, \mathrm{NO}_{2}^{-}\right.$ and $\mathrm{N}_{2} \mathrm{O}$ ) washed cells exhibited maximum activity at very high salt concentrations, but were lysed rapidly at $0.5 \mathrm{M}$ $\mathrm{NaCl}$ (supplementary Fig. S2b, available with the online version of this paper). The $\mathrm{pH}$ values suitable for growth tested under aerobic conditions for strains HLD $2^{\mathrm{T}}$ and HLD 16 were limited to a range from 6.5 to 8.2 , with an optimum between 7.3 and 7.8 .

When thiosulfate was replaced by thiocyanate $\left(\mathrm{NCS}^{-}\right)$, only a single anaerobic enrichment (from a mixture of sediment samples from the Kulunda Steppe lakes) gave a positive result at 1-2 $\mathrm{M} \mathrm{NaCl}$, in which the oxidation of thiocyanate to sulfate was linked to a complete reduction of nitrate to $\mathrm{N}_{2}$ gas. Serial dilutions were positive only up to $10^{-4}$ with four to five different morphotypes still present. However, replacement of thiocyanate by thiosulfate allowed selection of a binary co-culture, which reduced nitrate to $\mathrm{N}_{2}$ without intermediate nitrite accumulation at $1-2 \mathrm{M} \mathrm{NaCl}$. In this case the co-culture was more efficient than single HLD strains. The association consisted of thin rods as the dominant morphotype, and thick vibrios as a minor component. 


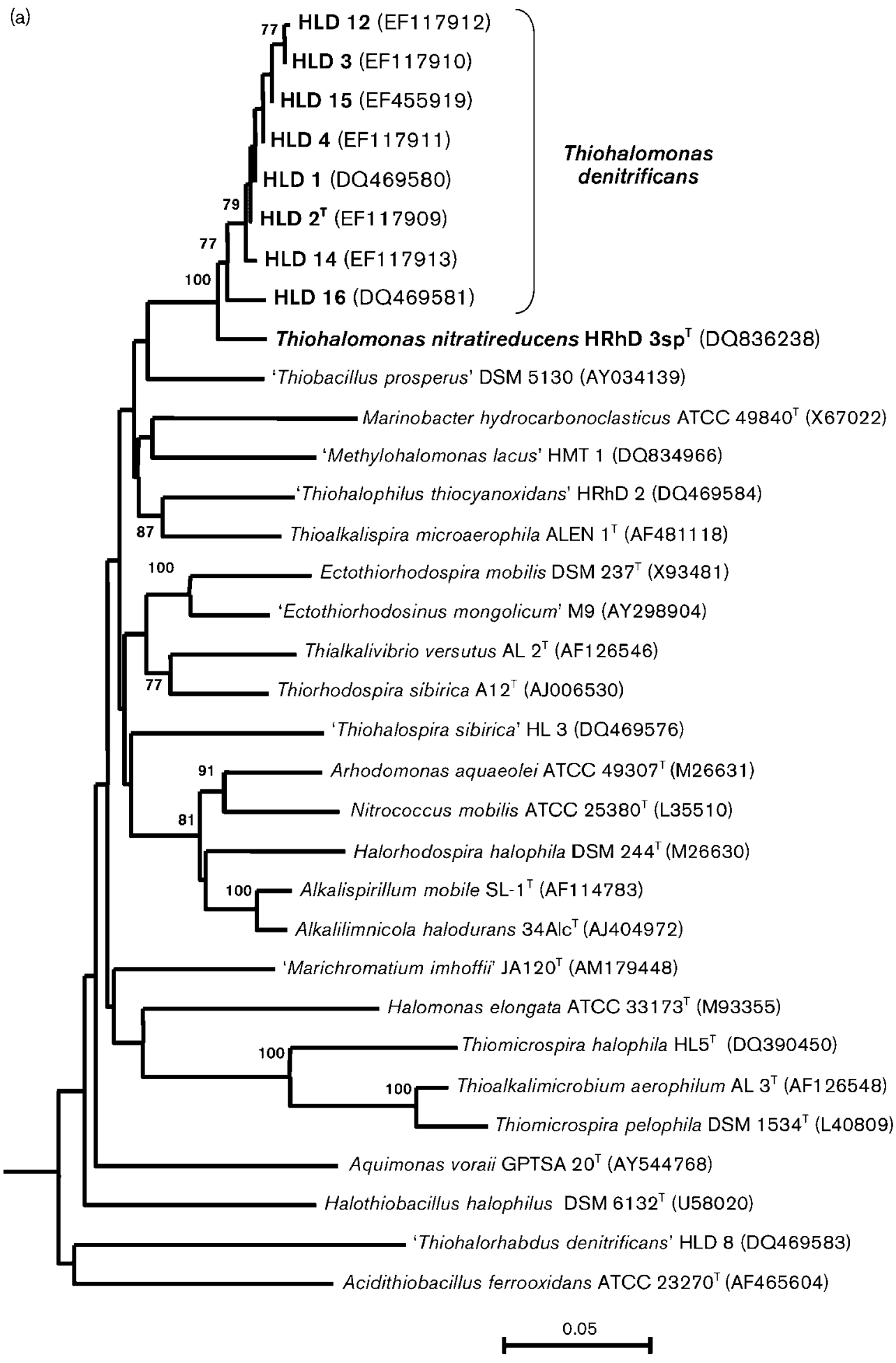

The co-culture was very stable and very difficult to separate into individual species. Final resolution of the co-culture resulted in the isolation of a pure culture of the nitratereducing, vibrio-shaped strain $\mathrm{HRhD} 3 \mathrm{sp}^{\mathrm{T}}$ (by sucrose gradient centrifugation) and the rod-shaped, nitritereducing strain $\mathrm{HRhD} 2$. The latter has recently been described as a new genus and species 'Thiohalophilus thio- cyanoxidans' (Sorokin et al., 2007). Strain HRhD $3 \mathrm{sp}^{\mathrm{T}}$ had vibrio-shaped, non-motile cells, the length of which depended on the growth conditions (Fig. 3). It had a capacity for anaerobic growth with thiosulfate (but not with thiocyanate) and nitrate, which was limited by high sensitivity to accumulating nitrite and an inability to reduce it further. Accumulation of $2.5-3.0 \mathrm{mM}$ nitrite completely 


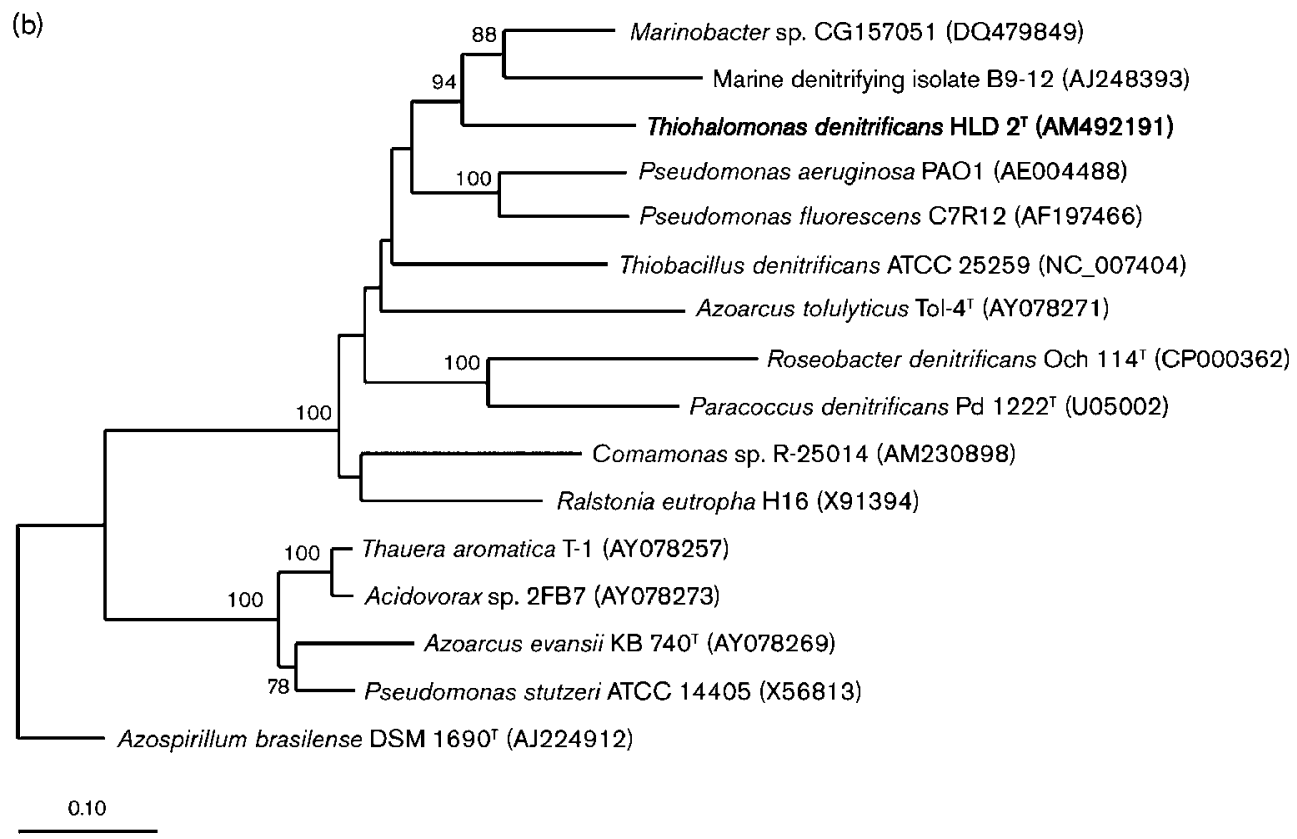

Fig. 2. Phylogenetic position of moderately halophilic, thiodenitrifying bacteria from hypersaline habitats within the Gammaproteobacteria based on 16S rRNA gene sequence analysis (a) and based on inferred amino acids (partial amplicons, $241 \mathrm{aa}$ ) of the nirS gene encoding a subunit of the cytochrome $c d_{1}$ type of dissimilatory nitrite reductase (b). The trees were reconstructed from evolutionary distances by using the neighbour-joining method. The scale bar represents five inferred nucleotide changes per $100 \mathrm{nt}$ (a) and 10 inferred amino acids changes per 100 aa (b). The percentage of bootstraps was derived from 100 (a) or 1000 (b) resamplings; values greater than $70 \%$ were considered as significant.

arrested growth and resulted in an incomplete oxidation of thiosulfate to elemental sulfur. This was probably the main reason for this bacterium growing in association with the nitrite-consuming thiodenitrifier. This conclusion was confirmed by growing $\mathrm{HRhD} 3 \mathrm{sp}^{\mathrm{T}}$ in a dialysis culture in which nitrite diffused out of the culture vessel; the culture reached a five times higher cell density than in ordinary batch mode. Growth in the presence of oxygen was irregular and only possible at oxygen concentrations below $5 \%$ in the gas phase. The $\mathrm{NaCl}$ tolerance range and optimum concentration of the nitrate-reducing isolate were lower than for the HLD strains (1.0-2.5 and 1.0 M, respectively). Phylogenetic analysis demonstrated that strain HRhD $3 \mathrm{sp}^{\mathrm{T}}$ is a member of the HLD cluster with a separate species status (97\% 16S rRNA gene sequence homology; see Fig. 2a), which was also confirmed by DNA-DNA hybridization with HLD $2^{\mathrm{T}}$ ( $40 \%$ homology).

Overall, the data presented demonstrate for the first time that the process of autotrophic thiodenitrification can be carried out at high salt concentrations in $\mathrm{NaCl}$ brines and that a novel, highly specialized group of Gammaproteobacteria is responsible for it. On the basis of phenotypic and genetic properties, the rod-shaped HLD strains capable of complete reduction of nitrate to $\mathrm{N}_{2}$ gas are proposed to be assigned to a new genus and species Thiohalomonas denitrificans gen. nov., sp. nov., while the vibrio-shaped, nitrate- reducing strain $\mathrm{HRhD} 3 \mathrm{sp}^{\mathrm{T}}$ is proposed as a second species of the new genus with the name Thiohalomonas nitratireducens sp. nov.

\section{Description of Thiohalomonas gen. nov.}

Thiohalomonas [Thi.o.ha.lo.mo' nas. Gr. n. thion sulfur; Gr. n. hals, halos salt; Gr. n. monas a unit, monad; N.L. fem. n. Thiohalomonas salt (-tolerant), sulfur-utilizing monad].

Cells are non-motile rods or vibrios with a Gram-negative cell wall. Obligately chemolithoautotrophic and facultatively anaerobic. Utilizes reduced sulfur compounds as electron donors with oxygen or nitrate as electron acceptors. Moderately halophilic and neutrophilic. Member of the Gammaproteobacteria. Habitat is hypersaline lakes and salterns. Type species is Thiohalomonas denitrificans.

\section{Description of Thiohalomonas denitrificans sp. nov.}

Thiohalomonas denitrificans (de.ni.tri'fi.cans N.L. v. denitrifico to denitrify; N.L. part. adj. denitrificans denitrifying).

In addition to the genus description, cells are long, nonmotile rods of variable size $(0.4-0.5 \times 2-6 \mu \mathrm{m})$ with a Gram-negative type of cell wall. Obligately chemolithoautotrophic. Utilizes sulfide and thiosulfate as electron donor 
Table 2. Fatty acid profile in polar lipids of strain HLD $2^{\top}$ in comparison with a moderately halophilic heterotrophic Gammaproteobacterium

Dominant fatty acids are in bold type. ND, Not determined. Data for Halomonas salina are from Valderrama et al. (1998).

\begin{tabular}{|c|c|c|}
\hline \multirow[t]{2}{*}{ Fatty acid } & \multicolumn{2}{|c|}{ Percentage of total } \\
\hline & HLD $2^{T}$ & Halomonas salina \\
\hline i10 & 0.42 & ND \\
\hline $10: 0$ & 0.33 & ND \\
\hline $3 \mathrm{~h} 10$ & 0.29 & $\mathrm{ND}$ \\
\hline $12: 1$ & 0.67 & ND \\
\hline $12: 0$ & 3.90 & 0 \\
\hline $14: 0$ & 0.53 & 0 \\
\hline $15: 0$ & 0.64 & 0.8 \\
\hline i16: 1 & 0 & $5-10$ \\
\hline $16: 1 \omega 7$ & 27.27 & ND \\
\hline $16: 1 \omega 5$ & 2.97 & ND \\
\hline $16: 0$ & 25.41 & 42 \\
\hline $10 \mathrm{Me} 16$ & 1.26 & 0 \\
\hline 9 Me16: 1 & 0 & ND \\
\hline $11 \mathrm{Me} 17: 1$ & 2.53 & 2.5 \\
\hline $\mathrm{i} 17: 1 \omega 5$ & 0 & 0.5 \\
\hline i17 & 0 & ND \\
\hline $17: 1 \omega 8$ & 0.91 & ND \\
\hline 17 cyc & 8.38 & ND \\
\hline $17: 0$ & 0.86 & ND \\
\hline $18: 1 \omega 9$ & 5.10 & 25 \\
\hline $18: 1 \omega 7$ & 11.84 & ND \\
\hline $18: 1 \omega 5$ & 1.64 & ND \\
\hline $18: 0$ & 0.49 & 5 \\
\hline $10 \mathrm{Me} 18$ & 0 & ND \\
\hline $11 \mathrm{Me} 18: 1$ & 1.29 & ND \\
\hline 19 сус & 3.26 & $5-10$ \\
\hline
\end{tabular}

with sulfate as the final oxidation product. Grows best anaerobically with nitrate as electron acceptor. Reduces nitrate completely to $\mathrm{N}_{2}$ with intermediate production of nitrite and $\mathrm{N}_{2} \mathrm{O}$. Can grow with oxygen as electron acceptor under micro-oxic conditions. Moderately halophilic with a salinity range for growth from 1.0 to $3.0 \mathrm{M} \mathrm{NaCl}$, and an optimum at 1.5-2.0 M. The $\mathrm{pH}$ range for growth is between 6.5 and 8.2 with an optimum between 7.3 and 8.2 . The

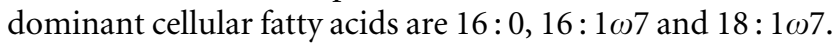
The $\mathrm{G}+\mathrm{C}$ content of the DNA is $58-60 \mathrm{~mol} \%\left(T_{\mathrm{m}}\right)$. Includes ten strains isolated from the sediments of hypersaline lakes and a solar saltern in Eurasia.

The type strain is HLD $2^{\mathrm{T}}\left(=\mathrm{DSM} 15841^{\mathrm{T}}=\mathrm{UNIQEM}\right.$ $\left.\mathrm{U} 222^{\mathrm{T}}\right)$. Isolated from sediments of hypersaline lakes in south-west Siberia. 16S rRNA gene sequence accession number is EF117909.

\section{Description of Thiohalomonas nitratireducens sp. nov.}

Thiohalomonas nitratireducens (ni.trat.i.re.du' cens. N.L. n. nitras nitrate; L. part. adj. reducens converting to a different state; N.L. part. adj. nitratireducens reducing nitrate).

In addition to the genus description, cells are non-motile vibrios of variable length $(0.5 \times 1-5 \mu \mathrm{m})$ with a Gramnegative type of cell wall. Obligately chemolithoautotrophic. Utilizes thiosulfate as electron donor with sulfate as the final oxidation product. Grows anaerobically with nitrate as electron acceptor, reducing it incompletely to nitrite. Anaerobic growth is inhibited by nitrite at concentrations above $2.5 \mathrm{mM}$. Can grow with oxygen as electron acceptor under micro-oxic conditions. Moderately halophilic with a salinity range for growth from 1.0 to $2.5 \mathrm{M} \mathrm{NaCl}$ and an optimum at 1.0 M. The $\mathrm{pH}$ optimum for anaerobic growth
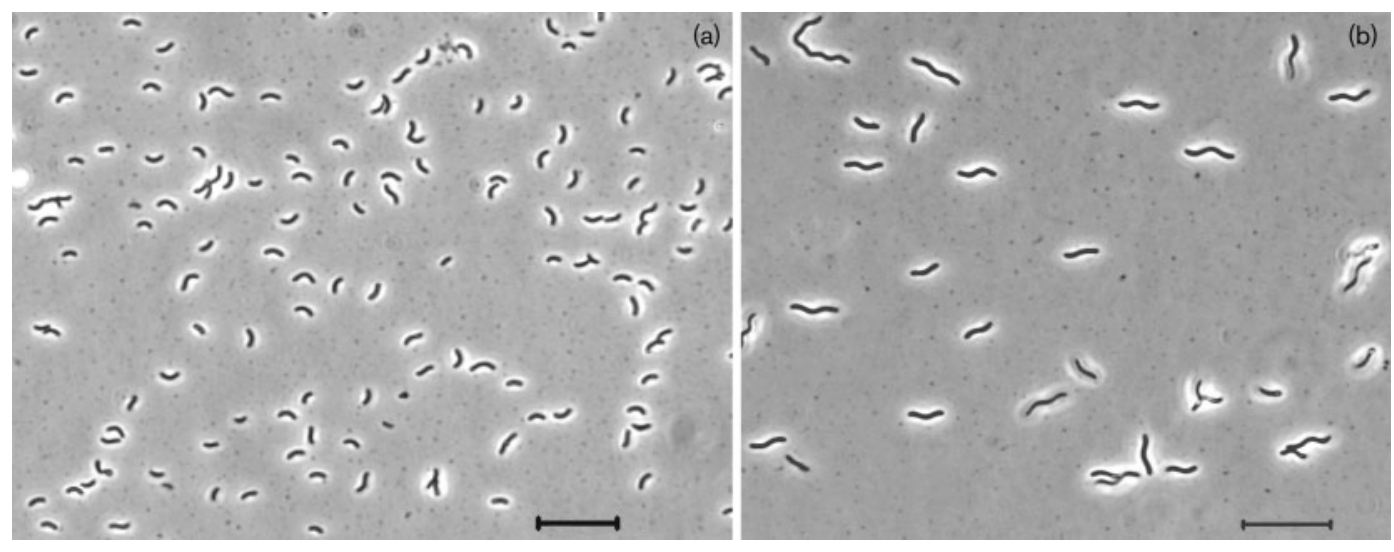

Fig. 3. Phase-contrast micrographs of moderately halophilic, nitrate-reducing strain $\mathrm{HRhD} 3 s p^{\top}$ grown anaerobically with $2 \mathrm{M}$ $\mathrm{NaCl}$ in batch (a) or dialysis (b) culture with thiosulfate and nitrate. Bars, $10 \mu \mathrm{m}$. 
is 7.8-8.0. The $\mathrm{G}+\mathrm{C}$ content of the DNA is $62.9 \mathrm{~mol} \%$ $\left(T_{\mathrm{m}}\right)$.

The type strain is HRhD $3 \mathrm{sp}^{\mathrm{T}}$ (=DSM $16925^{\mathrm{T}}=\mathrm{UNIQEM}$ $\mathrm{U} 248^{\mathrm{T}}$ ). Isolated from sediments of hypersaline lakes in south-west Siberia. 16S rRNA gene sequence accession number is DQ836238.

\section{Acknowledgements}

This work was supported by the NWO-RFBR (grant 47.011.2004.010), RFBR (grants 07-04-00153 and 05-04-48058) and by the Program of the Russian Academy of Sciences 'Molecular and Cell Biology'. We are grateful to $\mathrm{S}$. Fleissner for technical assistance in molecular work.

\section{References}

Antón, J., Oren, A., Benlloch, S., Rodríguez-Valera, F., Amann, R. \& Rosselló-Mora, R. (2002). Salinibacter ruber gen. nov., sp. nov., a new species of extremely halophilic bacteria from saltern crystallizer ponds. Int J Syst Evol Microbiol 52, 485-491.

Braker, G., Fesefeldt, A. \& Witzel, K.-P. (1998). Development of PCR primer systems for amplification of nitrite reductase genes (nirK and nirS) to detect denitrifying bacteria in environmental samples. Appl Environ Microbiol 64, 3769-3775.

De Ley, J., Caffon, H. \& Reinaerts, A. (1970). The quantitative measurements of hybridisation DNA from renaturation rates. Eur J Biochem 12, 133-140.

Felsenstein, J. (1989). PHYLIP - Phylogeny inference package (version 3.2). Cladistics 5, 164-166.

Jukes, T. H. \& Cantor, C. R. (1969). Evolution of protein molecules. In Mammalian Protein Metabolism, pp. 21-132. Edited by H. H. Munro. New York: Academic Press.

Marmur, J. (1961). A procedure for the isolation of deoxyribonucleic acid from microorganisms. J Mol Biol 3, 208-218.

Oren, A. (1999). Bioenergetic aspects of halophilism. Microbiol Mol Biol Rev 63, 334-348.

Oren, A. (2002). Halophilic Microorganisms and Their Environments. Dordrecht, The Netherlands: Kluwer.

Pfennig, N. \& Lippert, K. D. (1966). Über das Vitamin $B_{12}$-Bedürfnis phototropher Schwefelbacterien. Arch Microbiol 55, 245-256.

Schäfer, H. \& Muyzer, G. (2001). Denaturing gradient gel electrophoresis in marine microbial ecology. Methods Microbiol 30, 425-468.

Silva, M. T., Sousa, J. C. F., Polonia, J. J., Macedo, M. A. E. \& Parente, A. M. (1976). Bacterial mesosomes. Real structures or artifacts? Biochim Biophys Acta 443, 92-105.

Sorokin, D. Yu. \& Kuenen, J. G. (2005). Haloalkaliphilic sulfuroxidizing bacteria in soda lakes. FEMS Microbiol Rev 29, 685-702.

Sorokin, D. Yu., Kuenen, J. G. \& Jetten, M. (2001a). Denitrification at extremely alkaline conditions in obligately autotrophic alkaliphilic sulfur-oxidizing bacterium Thioalkalivibrio denitrificans. Arch Microbiol 175, 94-101.

Sorokin, D. Yu., Tourova, T. P., Lysenko, A. M. \& Kuenen, J. G. (2001b). Microbial thiocyanate utilization under highly alkaline conditions. Appl Environ Microbiol 67, 528-538.

Sorokin, D. Yu., Tourova, T. P., Antipov, A. N., Muyzer, G. \& Kuenen, J. G. (2004). Anaerobic growth of the haloalkaliphilic denitrifying sulphur-oxidising bacterium Thialkalivibrio thiocyanodenitrificans sp. nov. with thiocyanate. Microbiology 150, 2435-2442.

Sorokin, D. Yu., Tourova, T. P., Galinski, E. A., Belloch, C. \& Tindall, B. J. (2006a). Extremely halophilic denitrifying bacteria from hypersaline inland lakes Halovibrio denitrificans sp. nov. and Halospina denitrificans gen. nov., sp. nov., and evidence that the genus name Halovibrio (Fendrich 1989) with the type species $H$. variabilis should be associated with DSM 3050. Int J Syst Evol Microbiol 56, 379-388.

Sorokin, D. Yu., Tourova, T. P., Lysenko, A. M. \& Muyzer, G. (2006b). Culturable diversity of halophilic sulfur-oxidizing bacteria in hypersaline habitats. Microbiology 152, 3013-3023.

Sorokin, D. Yu., Tourova, T. P., Kolganova, T. V., Spiridonova, E. M., Berg, I. A. \& Muyzer, G. (2006c). Thiomicrospira halophila sp. nov., a novel, moderately halophilic, obligately chemolithoautotrophic sulfur-oxidizing bacterium from hypersaline lakes. Int J Syst Evol Microbiol 56, 2375-2380.

Sorokin, D. Yu., Tourova, T. P., Bezsoudnova, E. Yu., Pol, A. \& Muyzer, G. (2007). Denitrification in a binary culture and thiocyanate metabolism in Thiohalophilus thiocyanoxidans gen. nov. sp. nov. - a moderately halophilic chemolithoautotrophic sulfur-oxidizing Gammaproteobacterium from hypersaline lakes. Arch Microbiol 187, 441-450.

Valderrama, M. J., Monteoliva-Sanchez, M., Quesada, E. \& RamosCormenzana, A. (1998). Influence of salt concentration on the cellular fatty acid composition of the moderately halophilic bacterium Halomonas salina. Res Microbiol 149, 675-679.

Van de Peer, Y. \& De Wachter, R. (1994). TREECON for Windows: a software package for the construction and drawing of evolutionary trees for the Microsoft Windows environment. Comput Appl Biosci 10, 569-570.

Ventosa, A., Nieto, J. J. \& Oren, A. (1998). Biology of aerobic moderately halophilic bacteria. Microbiol Mol Biol Rev 62, 504-544.

Wayne, L. G., Brenner, D. J., Colwell, R. R., Grimont, P. A. D., Kandler, O., Krichevsky, M. I., Moore, L. H., Moore, W. E. C., Murray, R. G. E. \& other authors (1987). International Committee on Systematic Bacteriology. Report of the ad hoc committee on reconciliation of approaches to bacterial systematics. Int J Syst Bacteriol 37, 463-464.

Wood, A. P. \& Kelly, D. P. (1991). Isolation and characterisation of Thiobacillus halophilus sp. nov., a sulphur-oxidizing autotrophic eubacterium from a Western Australian hypersaline lake. Arch Microbiol 156, 277-280.

Zhilina, T. N., Zavarzin, G. A., Rainey, F. A., Pikuta, E. N., Osipov, G. A. \& Kostrikina, N. A. (1997). Desulfonatronovibrio hydrogenovorans gen. nov., sp. nov., an alkaliphilic, sulfate-reducing bacterium. Int J Syst Bacteriol 47, 144-149. 